\title{
PERANCANGAN ALAT UKUR TSS (TOTAL SUSPENDED SOLID) AIR MENGGUNAKAN SENSOR SERAT OPTIK SECARA REAL TIME
}

\author{
Ani Fatimah' ${ }^{1}$ Harmadi $^{2}$ dan Wildian ${ }^{2}$ \\ ${ }^{1}$ Program Pascasarjana FMIPA Universitas Andalas \\ ${ }^{2}$ Departemen Fisika, FMIPA Universitas Andalas, Padang 25163 \\ Email : anifatimah89@gmail.com
}

\begin{abstract}
ABSTRAK
Telah dirancang pengembangan sistem pengukuran TSS (Total Suspended Solid) dalam air menggunakan sensor serat optik secara real time. Sistem sensor serat optik mengukur nilai TSS dalam air memanfaatkan perubahan tegangan keluaran yang dihasilkan oleh fotodetektor akibat perubahan nilai TSS air. Rancangan sistem terdiri dari sumber cahaya berupa LED merah, serat optik FD-620-10, fotodioda OPT101, penguat istrumentasi IC INA114, mikrokontroler Arduino UNO dan program LabView sebagai penampil. Serat optik sepanjang 18,5 cm dikupas claddingnya sepanjang $5 \mathrm{~cm}$, dan dibersihkan menggunakan larutan aseton, selanjutnya digunakan sebagai probe sensor. Pengumpulan data dilakukan dengan membandingkan sistem yang dirancang dengan standar pengukuran menggunakan metode gravimetri. Data yang diperoleh melalui pengukuran dianalisis menggunakan teori kesalahan dan metode grafik. Rata-rata dari 10 data dalam 120 detik dengan metode gravimetri menghasilkan perbedaan maksimum $4 \mathrm{~V} /(\mathrm{mg} / \mathrm{L})$. Tegangan keluaran sensor berbanding terbalik dengan nilai TSS dalam air. Kesalahan relatif rata-rata didapatkan $4,04 \%$.
\end{abstract}

Kata kunci: TSS, serat optik, gravimetri, LabView

\section{PENDAHULUAN}

Air merupakan sumber daya alam yang berperan penting dalam kehidupan manusia, salah satunya adalah untuk dikonsumsi. Air yang digunakan untuk dikonsumsi harus bersih, tidak berbau, berasa dan berwarna dan sesuai standar yang telah ditetapkan oleh Kementrian Kesehatan. Menurut Peraturan Menteri Kesehatan Republik Indonesia nomor 492 tahun 2010 menyatakan Air minum adalah air yang melalui proses pengolahan atau tanpa proses pengolahan yang memenuhi syarat kesehatan dan dapat langsung diminum[1]. Untuk mengetahui air yang digunakan bersih dan sesuai standar yang ditetapkan oleh Kementrian Kesehatan, dilakukan pengujian terhadap kualitas air bersih.

Total Suspended Solid (TSS) adalah bahan tersupensi yang terdiri dari lumpur dan jasad renik yang berasal dari kikisan tanah atau erosi yang terbawa ke dalam air[2]. Sifat fisis suspensi, seperti titik beku atau tekanan uap suspensi padatan dalam cairan, kurang dipengaruhi oleh partikel yang tersuspensi. Jadi, air berlumpur membeku pada $0^{0} \mathrm{C}$ seperti halnya air murni. Partikel tersuspensi terlalu besar, dan jumlahnya terlalu kecil dibandingkan dengan jumlah molekul air dalam campuran sehingga pengaruhnya tidak terukur[3]. Partikel yang menurunkan intensitas cahaya yang tersuspensi dalam air umumnya terdiri dari fitoplankton, zooplankton, kotoran hewan, sisa tanaman dan sisa hewan yang sudah mati, kotoran manusia dan limbah industri[4]. Nilai TSS air dapat diketahui menggunakan metode gravimetri. Metode gravimetri adalah pemeriksaan jumlah zat dengan cara penimbangan hasil reaksi pengendapan. Langkah pengukuran pada gravimetri adalah pengukuran berat. Analit secara fisik dipisahkan dari semua komponen lainnya maupun dengan solvennya. Persyaratan yang harus dipenuhi agar gravimetri dapat berhasil ialah terdiri dari proses pemisahan yang harus cukup sempurna sehingga kualitas analit yang tidak mengendap secara analit tidak ditentukan dan zat yang 
ditimbang harus mempunyai susunan tertentu dan harus murni atau mendekati murni. Baku mutu air berdasarkan peraturan pemerintah No. 82 tahun 2001, batas ambang dari TSS dalam air yaitu $50 \mathrm{mg} / \mathrm{L}$ yang diukur dengan metode gravimetri[5].

Perkembangan ilmu pengetahuan dan teknologi yang demikian pesat di bidang elektronika dan instrumentasi telah memungkinkan diciptakannya alat-alat ukur yang bekerja secara tepat dan praktis. Serat optik dikembangkan menuju kearah sistem sensor yang dimodifikasi dan digunakan sebagai perangkat yang berinteraksi langsung dengan lingkungan. Penerapan serat optik sebagai sensor salah satunya dapat digunakan untuk pengukuran TSS air. Serat optik memiliki banyak kelebihan seperti kecepatan, tahan terhadap pengkaratan, dan harga relatif terjangkau[6]. Sistem sensor serat optik dirancang dengan menggunakan serat optik multimode step index. Bagian sensor penginderanya dilakukan dengan memodifikasi kabel serat optik, dimana pada bagian tengahnya mengganti cladding asli dengan TSS air.

Pada penelitian ini dilakukan pengembangan aplikasi kabel serat optik untuk mengukur TSS dalam air. Kabel serat optik dikupas cladding-nya pada bagian tengah, kupasan cladding ini akan mengindera perbedaan indeks bias dengan melakukan pembengkokan seperti huruf $U$. Prinsip kerja sensor serat optik berdasarkan sensor intensitas. Perubahan intensitas didasarkan pada nilai TSS dalam air yang dindera pada bagian cladding yang terkupas. Perubahan intensitas akan dideteksi oleh detektor, dimana perubahan intensitas ditandai dengan berubahnya tegangan keluaran. Sistem sensor serat optik diharapkan mampu untuk mengatasi permasalahan yang telah dikemukakan. Pengkajian secara teoritis dan desain instrumen perlu dilakukan sehingga diperoleh hasil yang memuaskan. Untuk memperoleh nilai TSS secara teori, berdasarkan Badan Standar Nasional dengan metode gravimetri dapat dihitung seperti Persamaan 1.

$$
T S S(m g / L)=\frac{(A-B) x 1000}{V}
$$

dengan $\mathrm{V}$ adalah volume sampel dengan satuan $(\mathrm{mL})$, A adalah massa akhir kertas saring dengan satuan (mg), dan B adalah massa awal dari kertas saring dengan satuan (mg).

\section{METODE PENELITIAN}

Sistem pengukuran TSS air menggunakan sistem sensor serat optik dengan metode evanescent. Serat optik melakukan penginderaan dengan cara memodifikasi cladding serat optik atau bisa disebut sistem sensor instrinsik[7]. Memodifikasi cladding bisa dilakukan dengan mengupas cladding asli serat optik, sehingga sampel air yang digunakan menjadi claddingnya. Serat optik sepanjang $18,5 \mathrm{~cm}$ dan diambil bagian tengahnya sepanjang $5 \mathrm{~cm}$ untuk dikupas claddingnya. Secara umum blok diagram sistem secara keseluruhan dapat diperhatikan pada Gambar 1.

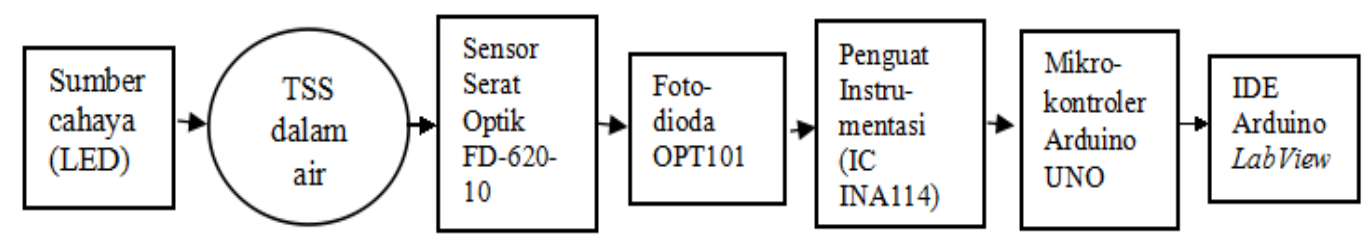

Gambar 1 Blok diagram sistem keseluruhan

Alat ukur TSS dalam air menggunakan sistem sensor serat optik ini menggunakan kabel serat optik sebagai pengindra. Kabel serat optik yang digunakan berjenis FD-620-10. 
Sebagai sumber tegangan sistem ini yaitu memanfaatkan catudaya teregulasi. Secara umum desain sistem secara keseluruhan dapat dilihat pada Gambar 2.

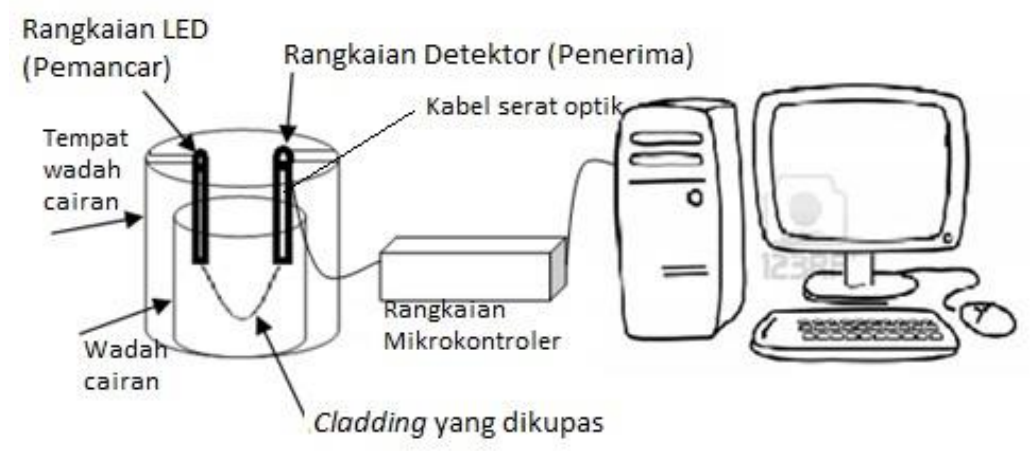

Gambar 2. Desain sistem pengukuran TSS dalam air

Gambar 2. memperlihatkan desain sistem pengukuran secara keseluruhan. Desain secara umum terdiri atas tiga bagian, yaitu bagian tempat detektor, tempat rangkaian (mikrokontroler) dan penampil (PC). Tempat detektor merupakan tempat sampel yang akan diukur nilai TSS. Nilai TSS dalam air diukur dengan menggunakan kabel serat optik yang ada bagian cladding terkupas. LED merah akan memancar cahaya melalui serat optik. Pandu gelombang cahaya akan terjadi didalam inti serat optik itu. Pada bagian akhir penjalaran sinar akan dideteksi dengan menggunakan detektor. LED dan detektor terletak pada bagian atas kotak detektor. Tempat rangkaian pada bagian luarnya terdapat tombol rangkaian mikrokontroler (Arduino UNO). Sinyal keluaran detektor akan dikuatkan sebanyak 50 kali sebelum diproses oleh mikrokontroler dan ditampilkan melalui PC (Personal Computer).

\section{HASIL DAN DISKUSI}

Hasil pengukuran yang telah didapatkan dalam pengukuran TSS dalam air menggunakan serat optik ditampilkan dalam bentuk grafik pada Gambar 3.

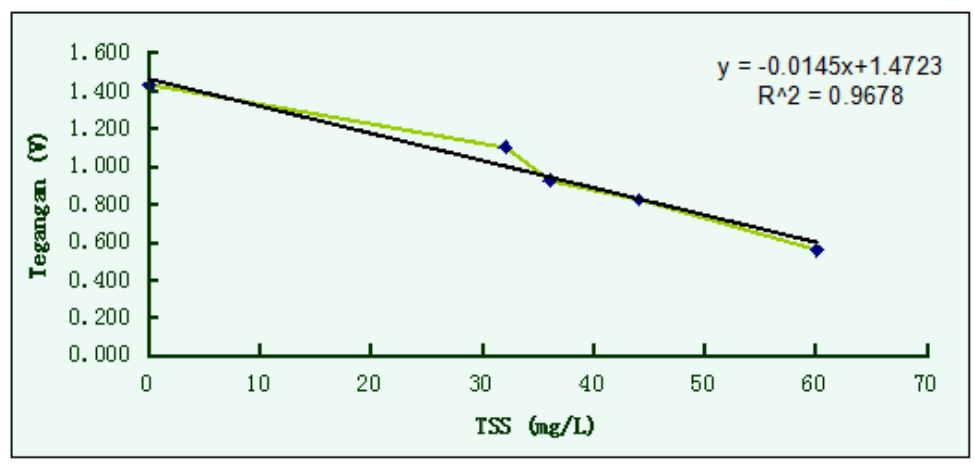

Gambar 3 Hubungan antara TSS dan tegangan keluaran

Dari Gambar 3 terlihat bahwa tegangan keluaran sensor berkurang seiring dengan peningkatan nilai TSS air yang diukur dengan metode gravimetri berdasarkan Persamaan 1 seperti terlihat pada Tabel 1 . 
Tabel 1 Pengujian TSS (Total Suspended Solid) dengan metode gravimetri

\begin{tabular}{|c|c|c|c|c|c|}
\hline Sampel & $\begin{array}{c}\text { Berat kertas } \\
\text { saring awal } \\
\text { (berat awal (gr)) }\end{array}$ & $\begin{array}{c}\text { Berat kertas saring }+ \\
\text { sampel } \\
\text { (Berat akhir (gr)) }\end{array}$ & $\begin{array}{c}\text { volume } \\
\text { sampel (ml) }\end{array}$ & $\begin{array}{c}\text { (Berat akhir - } \\
\text { Berat awal (gr)) }\end{array}$ & $\begin{array}{c}\text { TSS } \\
(\mathrm{mg} / \mathrm{L})\end{array}$ \\
\hline I & 1.0622 & 1.0630 & 25 & 0.0008 & 32 \\
\hline II & 1.0304 & 1.0313 & 25 & 0.0009 & 36 \\
\hline III & 1.0605 & 1.0616 & 25 & 0.0011 & 44 \\
\hline IV & 1.0432 & 1.0447 & 25 & 0.0015 & 60 \\
\hline
\end{tabular}

Penurunan tegangan keluaran sensor berhubungan secara linier dengan nilai TSS air. Melalui pendekatan garis lurus diperoleh persamaan $\mathrm{y}=1,4723-0,0145 \mathrm{x}$, dimana angka $-0,0145$ menyatakan sensitivitas sensor. Besarnya sensitivitas sensor adalah 0,0145 $\mathrm{V} /(\mathrm{mg} / \mathrm{L})$, artinya setiap kenaikan nilai TSS $1 \mathrm{mg} / \mathrm{L}$ sampel maka tegangan keluaran sensor akan berkurang sebesar $0,0145 \mathrm{~V}$ atau $14,5 \mathrm{mV}$. Tanda negatif berarti tegangan keluaran berkurang dengan peningkatan nilai TSS. Angka 1,4723 merupakan tegangan keluaran (dalam V) pada saat nilai TSS mendekati nol. Secara keseluruhan desain alat yang telah dibuat dapat dilihat pada Gambar 4.

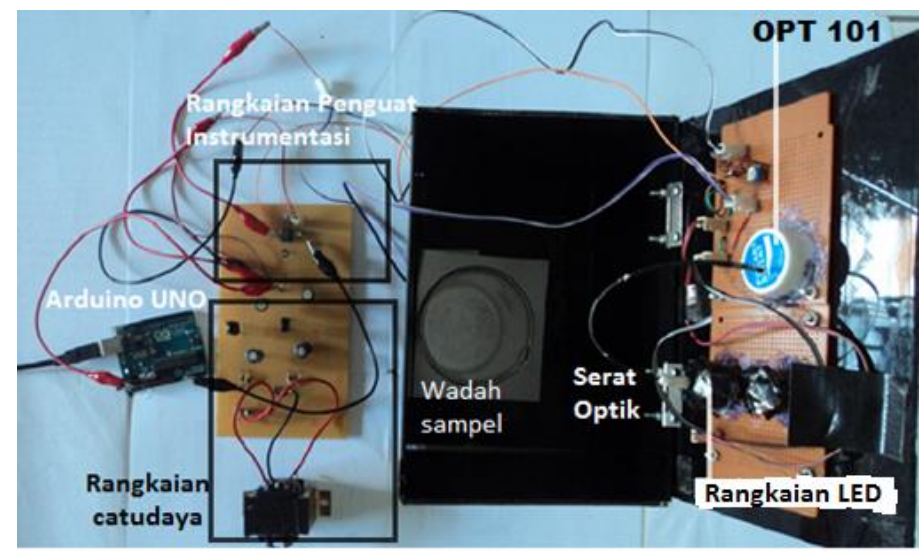

Gambar 4 Rangkaian keseluruhan alat ukur TSS air

Nilai sensitivitas yang didapatkan akan dimasukkan kedalam program LabView sebagai fungsi transfer. Pada program LabView juga didesain tampilan secara real time untuk mengetahui perubahan nilai TSS berdasarkan waktu pengamatan. Pengamatan dalam jangka waktu 120 detik, nilai rata-rata TSS dari 10 data tidak mengalami perubahan yang signifikan. Selain itu hasil pengukuran bisa disimpan dalam MS. Excell pada PC. Tampilan program LabView pada PC dapat dilihat pada Gambar 5.

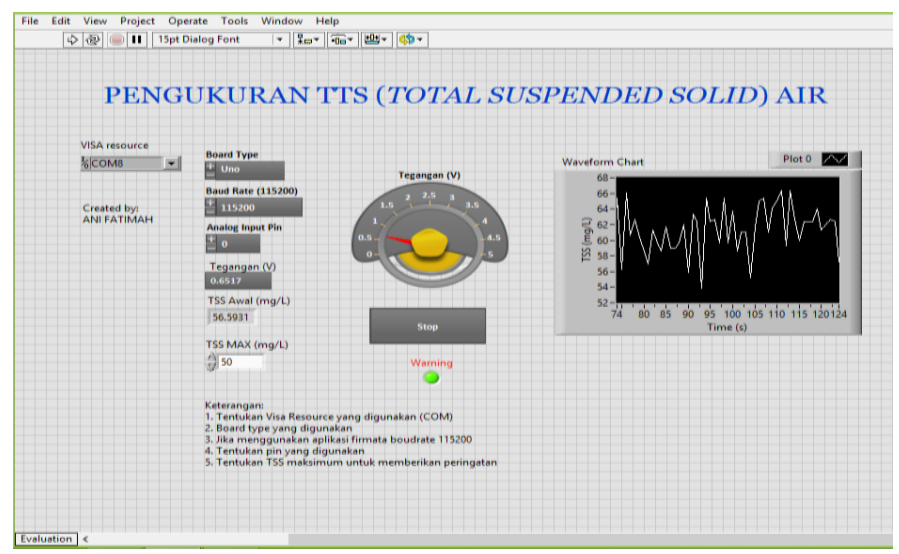

Gambar 5 Tampilan program LabView untuk pengukuran TSS air 
Hasil pengujian alat ukur TSS air minum secara keseluruhan dilakukan secara berulang sebanyak 5 kali dengan variasi nilai TSS air yang telah diukur dengan metode gravimetri. Berdasarkan data pengukuran berulang diperoleh hasil analitis statistik yang diperlihatkan pada Tabel 2.

Tabel 2 Data ketelitian pengukuran

\begin{tabular}{|c|c|c|c|}
\hline Sampel & TSS (mg/L) & TSS rata-rata & Persen Error (\%) \\
\hline I & 32 & 31.78 & 0.68 \\
\hline II & 34 & 36.71 & 7.98 \\
\hline III & 44 & 43.08 & 2.07 \\
\hline IV & 60 & 63.26 & 5.44 \\
\hline
\end{tabular}

Dari hasil analisis data pada Tabel 2 dapat dijelaskan tingkat ketelitian dari pengukuran. Kesalahan relatif dari sistem pengukuran TSS air berkisar antara 0,68\% sampai 7,98\%. Ketelitian pengukuran dibandingkan dengan metode gravimetri memiliki perbedaan nilai TSS maksimal kurang dari $4 \mathrm{mg} / \mathrm{L}$. Pada Tabel 1 terdapat nilai TSS pada sampel air minum melebihi standar yang ditentapkan Kementrian kesehatan yaitu maksimum 50 $\mathrm{mg} / \mathrm{L}$. Setelah ditelusuri ada kandungan fluorida $0,5 \mathrm{mg} / \mathrm{L}$ dalam air minum, tetapi hal tersebut masih dalam batas standar yang ditetapkan oleh Kementerian Kesehatan yang membatasi kandungan Fluorida maksimum 1,5 mg/L. Hal tersebut perlu dikaji ulang berdasarkan sifat-sifat kimia yang terkadung dalam sampel. Apakah nilai TSS tersebut masih baik untuk kesehatan atau tidak. Hal lain disebabkan oleh faktor lingkungan seperti suhu, tegangan, dan gerakan yang tidak stabil.

\section{KESIMPULAN DAN SARAN 4.1 Kesimpulan}

Berdasarkan data hasil dan analisis terhadap besaran yang terdapat dalam sistem pengukuran TSS air menggunakan sensor serat optik dapat ditarik kesimpulan bahwa besarnya sensitivitas sensor serat optik adalah $0,0145 \mathrm{~V} /(\mathrm{mg} / \mathrm{L})$, artinya setiap kenaikan nilai TSS $1 \mathrm{mg} / \mathrm{L}$ sampel maka tegangan keluaran sensor akan berkurang sebesar 0,0145 $\mathrm{V}$ atau $14,5 \mathrm{mV}$. Persentase kesalahan dari sistem pengukuran TSS air berkisar antara $0,68 \%$ sampai $7.98 \%$. Ketelitian pengukuran dibandingkan dengan metode gravimetri memiliki perbedaan nilai TSS maksimal kurang dari $4 \mathrm{mg} / \mathrm{L}$. Kekeruhan tidak selalu mempengaruhi nilai TSS, adakalanya nilai kekeruhan yang tinggi menghasilkaan nilai TSS yang rendah, begitu juga sebaliknya karena kekeruhan hanya bersifat optis sedangkan TSS ditinjau dari sifat optis dan partikel yang terkandung dalam air.

\subsection{Saran}

Berdasarkan pembahasan yang telah dilakukan maka dapat dikemukakan saran sebagai berikut yaitu penelitian masih dalam bentuk desain sistem yang digunakan di laboratorium dengan tampilan pada PC, untuk lebih memudahkan penggunaan di lapangan sebaiknya menggunakan tampilan pada LCD (Liquid Crystal Display) yang sudah dilengkapi tampilan grafik di dalamnya dan perlu diteliti lagi penambahan beberapa variasi sampel air, sehingga didapatkan data yang lebih presisi.

\section{DAFTAR PUSTAKA}

1. Kementerian Kesehatan, 2010, Undang-undang Nomor 492 Tahun 2010 tentang Persyaratan Kualitas Air Minum, Jakarta.

2. Barlin, 1995, Analisa dan Evaluasi Hukum Tentang Pencemaran Akibat Air Limbah Rumah Sakit, Badan Pemberian Hukum Nasional, Jakarta.

3. Brady, J., 1994, Kimia Universita Asas dan Struktur, Erlangga, Jakarta.I 
4. Sunu, Pramudya, 2001, Melindungi Lingkungan Dengan menerapkan ISO 14001. PT.Gramedia Widiasarana Indonesia, Jakarta.

5. Peraturan Pemerinntah Republik Indonesia, 2001, Undang-undang Nomor 82 Tahun 2001 tentang Persyaratan Kualitas Air Minum dan Pengendalian Pencemaran Air, Jakarta.

6. Wibowo, R., Rubiyanto, A., 2012, Desain Sensor Konsentrasi Larutan NaCl Menggunakan Serat Optik moda Jamak Dengan Model W system, Jurnal Sains dan Seni ITS, Vol. 1, No.1, B70-B72.

7. Castrellon, J. 2002. Optical Fiber Sensors: An Overview. Autonomous University of Morelos State, Meksiko. 